\title{
Building Partner Cooperation between Teachers and Parents
}

BARBARA ŠTEH ${ }^{* 1}$ AND JANA KALIN ${ }^{2}$

$\approx$ This paper presents the goals of teacher-parent cooperation, various potential models for establishing mutual cooperation, and the conditions required to achieve quality interactive cooperation. The partnership model is highlighted as an optimal model of interactive cooperation between teachers and parents, as it includes the distribution of expertise and control with the purpose of ensuring optimal education for children. It enables the creation of an interactive working relationship in which all of those involved are respected and recognised in their efforts to achieve common goals.

The second part presents the findings of an empirical study carried out on a representative sample of Slovene primary schools. Teachers $(\mathrm{N}=$ $467)$ and parents $(\mathrm{N}=1,690)$ were asked to express their opinions about the need for mutual cooperation, their view of each other when fulfilling their respective roles, and where they perceive the main obstacles to mutual cooperation. It became evident that teachers and parents have doubts about each other's competence. This does not form a solid base on which to establish and build the necessary partner relationship, and along with it mutual cooperation. Yet both groups to a large extent agree that teacher-parent cooperation is both necessary and useful. This gives rise to the question as to how to ensure that schools adopt policies promoting opportunities for better understanding, for building quality mutual relations and for parents to become more actively involved.

Keywords: Models of mutual cooperation, Obstacles to cooperation, Partnership model, Teachers and parents

$1 \quad{ }^{\star}$ Corresponding author. Faculty of Arts, University of Ljubljana, Slovenia barbara.steh@guest.arnes.si

2 Faculty of Arts, University of Ljubljana, Slovenia jana.kalin@guest.arnes.si 


\section{Graditev partnerskega sodelovanja med učitelji in starši}

BARbara ŠTEH* IN JANA KaLIN

$\propto V$ prispevku so predstavljeni cilji sodelovanja med učitelji in starši, različni mogoči modeli vzpostavljanja medsebojnega sodelovanja in pogoji za doseganje kakovostnega medsebojnega sodelovanja. Izpostavljen je partnerski model kot optimalni model medsebojnega sodelovanja med učitelji in starši, saj vključuje delitev ekspertnosti in nadzora z namenom zagotoviti optimalno izobraževanje za otroke. Omogoča ustvarjanje medsebojnega delovnega odnosa, v katerem se spoštuje in upošteva vse vpletene $\mathrm{v}$ prizadevanju za doseganje skupnih ciljev. V drugem delu predstavljamo izsledke empirične študije, izvedene na reprezentativnem vzorcu slovenskih osnovnih šol. Učitelje $(\mathrm{N}=467)$ in starše $(\mathrm{N}=$ 1.69o) smo spraševali o njihovem mnenju o potrebnosti medsebojnega sodelovanja, o tem, kakšen je njihov pogled drug na drugega pri izpolnjevanju svojih vlog, ter v čem vidijo poglavitne ovire za medsebojno sodelovanje. Pokazalo se je, da učitelji in starši dvomijo o kompetentnosti drug drugega, kar ne predstavlja dobre osnove za vzpostavljanje partnerskega odnosa in sodelovanje drug z drugim. Oboji pa se v veliki meri strinjajo, da je sodelovanje učiteljev in staršev potrebno in koristno. Zastavlja se torej vprašanje, kako v okviru šole zagotoviti možnosti za boljše medsebojno razumevanje, graditev kakovostnih medosebnih odnosov in aktivnejše vključevanje staršev.

Ključne besede: modeli medsebojnega sodelovanja, ovire za sodelovaje, partnerski model, učitelji in starši 


\section{Introduction}

Numerous studies confirm that it is important to attract parents to cooperation with the school and teachers, in order to comprehensively encourage the child's development (Burden, 1995; Gonzalez-DeHass, Willems, \& Doan Holbein, 2005; Henderson \& Berla, 1994; Jordan, Orozco, \& Averett, 2001; Lewis, Kim, \& Bey, 2011; Pomerantz, Moorman, \& Litwack, 2007; Soo-Yin, 2003). Referring to various studies, Hornby (2000), for example, points out the numerous benefits on different levels resulting from the active involvement of parents in school life. These benefits include improving parents' opinions of teachers and schools, and also of their pupils, resulting in a reduction in negative behaviour amongst pupils, thus achieving a more appropriate school atmosphere. These positive changes foster improved communication between parents and children, leading to a rise in parents' expectations of their children, etc., which in turn brings about an improvement in pupils' learning habits and a corresponding improvement in academic achievements. Researchers have confirmed that the overall involvement of parents represents a positive contribution to learning and the learning achievements of pupils (Hendeson \& Berla, 1994; Hoover-Dempsey \& Sandler, 1997 in Gonzalez-DeHass et al., 2005). These studies prove that there is a close relationship between the involvement of parents and pupils' learning achievement, their wellbeing, their attendance at school, their views, their homework assignments, their school marks and their educational aspirations. This is also linked to higher learning achievements of pupils, the time spent on their homework, a more favourable attitude towards school and a lower number of pupils who quit school ("dropouts").

All of these effects naturally differ according to the degree and quality of parents' direct involvement, but certain effects are already present if parents are regularly informed of their child's progress (Swap, 1993 in Hornby, 2000). Woolfolk (2002) points out that teachers can create a more positive classroom environment, allowing them to dedicate more time to teaching, when they share the same expectations as parents and when both sides support each other. The goals of mutual cooperation between teachers and parents are thus evident. However, this gives rise to the question as to what form such cooperation should take, and how to establish and develop it.

\section{Models of establishing teacher-parent relationships}

Teachers may assume very diverse attitudes towards parents, ranging from seeing them as a problem, as competitors, as too vulnerable and needing 
help, through the belief that a professional distance has to be kept towards parents, and finally to the opinion that they can provide a valued support in educating their children and can act as good collaborators. The key factor for fruitful cooperation is whether the teacher can engage in dialogue with parents on an equal basis and see them as partners in mutual educational activities and problem solving. On the other hand, the teacher may place parents in an inferior position, where parents mainly have to be taught, or in a superior role, where teachers feel that they need to apologise for and justify their own actions. In establishing and maintaining equal roles or a partnership between teachers and parents, it is worth keeping in mind that both teachers and parents are experts: teachers on education and parents on their own children (Hornby, 2000). It is only possible to cooperate creatively if parents' powers and competence are recognised and taken into account (O'Callaghan, 1993 in Čačinovič-Vogrinčič, 1999). We often underestimate the importance of information that parents can reveal to us about their children, while, on the other hand, we as teachers can disclose to parents how their child performs in the school environment not only at the cognitive but also at the emotional and social level. In addition, teachers should be competent in creating an optimal and encouraging learning environment that eases and encourages the learning process. The views of both groups can, of course, be subjective, due to the position from which they enter the relationship. Parents are, as can be expected, usually "advocates" for their own children (Henry, 1996 in Čačinovič-Vogrinčičc, 1999); they are emotionally bound to their own child and have difficulty accepting certain "truths" about him or her. Nor are teachers as independent in their own views as it would seem at the first sight, as they are part of a system that poses its own demands and value criteria, which can also limit the teacher's perspectives (for example, their image of a "good, obedient pupil", and of a "good teacher" who sticks to the rules). If parents and teachers manage to trust one another and to be frank with one another, they can view pupils, each other and their problems in a more realistic light, thus contributing to their more efficient cooperation.

Two extremes of parent-teacher relationships are pointed out above: on the one hand, there is a relationship with the necessary submission of one party - usually parents, but sometimes also teachers - while, on the other hand, there is a partnership. Approaches to establishing relationships between teachers and parents can be differentiated and classified ranging from those that downplay the involvement and active role of parents to those that emphasise it. Hornby (2000) lists the following models of establishing teacher-parent relationships, defined by varied sets of assumptions, goals and strategies:

1. In the protective model (Swap, 1993 in Hornby, 2000), it is important 
to avoid conflicts between teachers and parents. This is best achieved through a total separation of teaching and parenting. Education is the school's and teachers' task, and parent involvement can be perceived as a disturbing interference. Swap (1993 in Hornby, 2000) considers this to be the most common model of teacher-parent relationship.

2. In the expert model (Cunningham \& Davis, 1985 in Hornby, 200o), teachers consider themselves as experts in all aspects of the development and education of children. The role of parents is to accept information and instructions regarding their children, and they are pushed into a completely submissive role and into dependence. Parents are not supposed to question teachers' decisions and thus lose confidence in their own competence, while, at the same time, teachers with such an attitude are not admitted to the rich source of information that parents have about their children and often overlook important problems or abilities of pupils.

3. In the transmission model (Swap, 1993 in Hornby, 2000), teachers still consider themselves as the major source of expertise, but they accept that parents can play an important role in enhancing their child's progress. They present particular measures to parents and expect them to carry them out.

4. In the curricular enrichment model (Swap, 1993 in Hornby, 2000), the parents' contribution can enrich the curriculum and thus significantly enhance a school's educational goals. It is a good opportunity for teachers and parents to learn from each other. The problem is that parents thus enter the area of teaching and many teachers find this threatening.

5. In the consumer model (Cunningham \& Davis, 1985 in Hornby, 2000), parents have control over decisions. The teachers' role is to present all of the relevant information and available possibilities to parents and to help them choose the optimal course of action. This eliminates the fear that parents are pushed into a dependent role, but the fact that teachers lose their professional responsibility is problematic in the same way as the opposite situation where teachers are seen as experts on all aspects of the child's development. Establishing teacher-parent cooperation based on this model is undoubtedly present in the Slovene environment, and it would be interesting to investigate how often teachers are pushed into a role in which they have to carry out requirements imposed by others (ranging from detailed instructions on various rules to parents' requirements regarding issues such as whether a teacher is permitted to punish a pupil, to give home work, etc.), as such cases take away teachers' professional autonomy. 
6. The most suitable model of teacher-parent cooperation is the partnership model, as it includes the sharing of expertise and control with a view to ensuring the optimal education for children, to which both teachers and parents contribute. Naturally, it is not possible to establish such a partnership if there is no mutual respect between teachers and parents. Teachers and parents should listen to each other's opinions and take them into account. A partnership occurs when there is mutual planning and sharing of responsibilities, as well as a certain long-lasting involvement and the carrying out of particular activities. Hornby (2000) points out four key elements of such partnership:

- two-way communication,

- mutual support,

- common decision-making,

- encouraging learning.

Within the framework of a partner relationship, some authors particularly stress the importance of establishing a work union or working relationship that may be denoted as participative efforts to attain common goals. Typically, such a relationship is oriented towards both "here and now" and towards the future, it focuses on the positive and optimistic, it is a meeting point of equal parties who respect and recognise the competences of others involved, as well as recognising sources of power, beliefs, knowledge and experience that have been effective in the past (Čačinovič Vogrinčič, Kobal, Mešl, \& Možina, 2005, Shazer, 1985 boath in Šteh \& Mrvar, 2011a).

The partnership model is often perceived as the most suitable model for developing constructive parent involvement (Esler, Godber, \& Christenson, 2000; Hornby, 2000), as teachers also take parents' needs into account and are aware of various manners in which parents can contribute to the development and education of their children. However, this does not mean that this model is the most suitable for all situations. It is important to be flexible and to adapt the approach to parents' characteristics.

When planning cooperation with parents, it is naturally important that we are aware of obstacles in parents. "Research conducted in the 1980 os and 1990 s searching for variables related to differences in parental involvement focused on deficiencies of parents" (Edwards \& Warin, 1999 in Lewis et al., 2011, p. 221). In the 21st century, especially under the influence of studies by Epstein, the focus has shifted from studying parents' deficiencies and reasons why they are unable to cooperate with school to critically analysing the existing practice and improving school practice towards promoting "active parental participation", 
since the school oversees several relevant resources, particularly in the area of adequate teacher training (Lewis et al., 2011).

\section{Conditions of efficient cooperation between teachers and parents}

It is important for every school to encourage and facilitate teacher-parent partnerships that increase the involvement of parents and their participation in encouraging the social, emotional and intellectual development of their child (Children's Defence Foundation 2000 in Soo-Yin, 2003). School, parents and the community should be aware of their interaction and should together create a vision and understand the role of individual factors in relation to the roles of others. Such cooperation is necessary to ensure the support and assistance that every child needs to succeed at school.

For this purpose, it is important to create an appropriate school culture determined by the values, attitudes and behavioural patterns typical of the school as a whole (Rutter, Maughan, Mortimore, Ouston, \& Smith, 1980 in Bečaj, 1999). These factors to a great extent determine the establishment of mutual relationships and the methods of communication between teachers and parents. In this way, they also determine the characteristics of the mutual cooperation model. It is important to note that the school becomes and remains a so-called "learning organisation", for which discussions, creativity, activity, participation, cooperation, flexibility, acceptance of risk, evaluation, reflection and a developmental attitude are typical (Holly \& Southworth, 1989). The development of school as an institution cannot be imagined without the development of a culture of participation among the employees, learning with each other and one from another, in constant connection and cooperation between teachers, parents and the wider social community. For teachers, both appropriate beliefs and qualifications are necessary to achieve these purposes.

In relation to this, we have to be constantly aware that parents are a very heterogeneous group of individuals and that we have to adapt our activities and methods of cooperation accordingly (Šteh \& Mrvar, 2011b). The more varied forms of cooperation and involvement we offer parents, the more chance there is of attracting them to cooperate. Parents' involvement and cooperation also differ in relation to their characteristics, needs and qualifications (Kalin \& Šteh, 2008). Moreover, it is important that teachers are sensitive to obstacles (objective and subjective) that may prevent parents from becoming more actively involved, and that they endeavour to remove such obstacles. "Parental participation in school, including participation by minority parents, increases when teachers demonstrate more receptive and supportive attitudes toward parental 
participation at school and actually reach out to parents to bring them into the school" (Desimone, Finn-Stevenson, \& Henrich, 200o, Deslandes \& Bertrand, 2005, Epstein, 1984, 1986, Kohl, Lengua, \& McMahom, 2000 all in Lewis et al., 2011, p. 221). It is particularly worth making an effort at the beginning and establishing two-way communication, in order for parents and teachers to have an opportunity to get to know each other, to clarify their expectations and to further build their relationship. A teacher has various methods available, from sending personal messages or "class letters" to all parents, making telephone calls, using pupils as carriers of messages, to feedback regarding the pupil's learning achievement, monthly descriptions of the pupil's progress, etc. Parents need to feel that teachers are not indifferent towards their child and that parents' support is both welcome and required in the education of their children (Lewis et al., 2011).

The more teachers try to intensify parents' involvement and to establish a partnership relationship, the more participation, communication and organisation skills teachers have to master. Hornby (2000) points out the following:

- mastering the basic skills of listening and counselling,

- $\quad$ skills of assertive communication,

- $\quad$ organisational and communicational skills to maintain contacts with parents (meetings, e-mails, telephone calls, etc.),

- $\quad$ skills in involving parents in the educational programmes of their children (in organising learning, in adjusting learning, in encouraging motivation, in building self-respect, etc.)

- $\quad$ skills of leading a group, so that various group meetings for parents can be organised.

At this point, we would particularly highlight listening and assertive skills. Usually teachers have well-developed skills for transmitting information and explaining, but their listening skills are not always as advanced. It is probable that they see themselves more in the role of a speaker, a transmitter of information and advice, rather than in the role of a listener. It is crucial for them to become aware of how important it is for them to be able to listen - to their pupils and colleagues and, of course, to parents. Ineffective communication may occur because we do not listen to the person to whom we are speaking and are absorbed in our own thoughts, because we selectively receive information sent by the interlocutor and interpret it according to our own expectations and anticipated prejudices, according to our relation towards the sender of the message or towards its content, etc.; we can also unconsciously convey unintended messages (Jaques, 2000). When parents were asked about how they would want 
teachers to change, a very frequent answer was simply that they should listen better (Hornby, 2000). In listening it is not enough only to hear, but to be ready to understand, which is a psychological and not merely a physiological process.

On the other hand, teachers often have to face criticism, aggressive behaviour and unrealistic demands. In such circumstances, it is important that teachers are able to express their feelings, needs and demands clearly, peacefully and without any hostility - they need to be assertive in their behaviour (Hornby, 2000; Woolfolk, 2002). The most demanding task for them may be to distinguish between situations in which they primarily have to lend an ear and situations where they have to make clear demands. Actually, they need both types of skills in their mutual cooperation with colleagues, pupils and parents: whenever they discuss measures and tasks of the one group or another, when they plan common activities and during the process of mutual problem solving.

In order to acquire participation and communication skills, teachers need additional training. However, training for these skills is not enough alone; teachers' willingness to understand and help is essential for the success of their work with pupils and parents (Kottler \& Kottler, 2001), together with their trust in the ability of pupils and parents to find their own powers or to additionally develop their problem-solving competence (O’Callaghan, 1993, Saleebey, 1997 boath in Čačinovič-Vogrinčič, 1999). If we highlight a partner or working relationship as our goal, it is crucial to know whether teachers are prepared for such a relationship, whether they believe their efforts will be fruitful and whether they are genuine, respectful and emphatic in their interpersonal communication (Hornby, 2000). Still, teachers are not all-powerful, and it is right that pupils and parents take their own share of responsibility for effective learning and mutual cooperation.

\section{The purpose of the research}

Within the goal-oriented research project "Levers of successful cooperation between the school and home: modern solutions and perspectives" (Kalin et al., 2008) we were interested in how teachers and parents evaluate mutual cooperation and what the key problems of such cooperation are. We devoted special attention to identifying drivers of change - the improvement of cooperation between school and family, teachers and parents. In this paper, we will limit our discussion to the part of the findings linked to the following research questions:

1. What are teachers' and parents' attitudes to the benefits and necessity of mutual cooperation?

2. What do teachers themselves think of the view parents have of them? 
How do parents view teachers? Do they see them as experts on education or not?

3. To what extent do teachers and parents agree that today parents know how to be parents, and that they need additional education in parenting and family education problems?

4. What obstacles to mutual cooperation are highlighted by teachers and by parents?

5. Are there any statistically significant differences between teachers and parents in answering the above questions?

6. Are there statistically significant differences between parents in answering the above questions depending on their level of education?

\section{Method}

We used a descriptive and causal-non-experimental method of pedagogical research. The basic population included all of the primary schools in Slovenia $(\mathrm{N}=448)$, which were further divided into two strongly distinguished strata, namely urban $(\mathrm{N}=237)$ and non-urban schools $(\mathrm{N}=211)$. The strata were conceived as independent groups within the entire basic group. We then randomly selected 20 urban and 20 non-urban primary schools from these strata, thus forming a random sample at the first level. At each school, we selected 'a' classes of the $3^{\text {rd }}$ grade, $5^{\text {th }} / 6^{\text {th }}$ grade and $9^{\text {th }}$ grade and distributed questionnaires to the pupils' parents. We received $1,690^{3}$ completed questionnaires from parents. We intended to include in the research all of the class teachers from all 40 schools from the random sample, and we sent 713 questionnaires to these teachers. We received 467 (65.5\%) completed questionnaires.

Anonymity was ensured to both teachers and parents. Questionnaires for teachers and parents contained multiple choice questions, scales and openended questions. We sent the questionnaires to schools by post in November 2007 , and we received the completed questionnaires towards the end of December 2007 and in the beginning of January 2008. The data was processed with the SPSS statistical package, using descriptive statistical and the hi-square test, or the Kullback $2 \hat{I}$ test in cases where the expected count was less than five in more than $20 \%$ of the boxes of the contingency table. 


\section{Results and discussion}

\section{Teachers' and parents' attitudes to the benefits and necessity of mutual cooperation}

Teachers and parents show statistically significant differences in their attitudes towards the statement that the cooperation of school and parents is necessary and useful $(2 \overline{\mathrm{I}}=173.369 ; \mathrm{df}=4, \mathrm{a}=0.000) .76 .8 \%$ of teachers and $43.1 \%$ of parents absolutely agree that such cooperation is necessary and useful. Teachers express a high degree of agreement with the statement, while parents show a little more caution. These conclusions may be a challenge for teachers and parents to justify and word the purpose and usefulness of the cooperation between school and parents. If teachers alone predominantly agree with such cooperation, it does not mean that it will, in fact, be useful and effective. Most parents are aware that their cooperation with school is important; however, they may need support in clarifying their role in order to predominantly express complete agreement with the necessity and usefulness of mutual cooperation. Epstein (1990 in Hornby, 2000) establishes that most parents are interested in the education of their children but fail to know what schools expect of them and how they can contribute to the schooling of their children.

Table 1: Teachers' and parents' attitudes to the benefits and necessity of mutual cooperation.

\begin{tabular}{|l|l|c|c|c|c|c|c|}
\hline \multicolumn{2}{|c|}{} & \multicolumn{5}{c|}{ Cooperation of school and parents is necessary and useful. } \\
\cline { 3 - 8 } & & $\begin{array}{c}\text { I absolutely } \\
\text { disagree }\end{array}$ & $\begin{array}{c}\text { I do not } \\
\text { agree }\end{array}$ & $\begin{array}{c}\text { I partially } \\
\text { agree }\end{array}$ & I agree & $\begin{array}{c}\text { I absolutely } \\
\text { agree }\end{array}$ & Total \\
\hline \multirow{2}{*}{ Parents } & f & 1 & 8 & 114 & 789 & 692 & 1604 \\
\cline { 2 - 8 } & f\% & .1 & .5 & 7.1 & 49.2 & 43.1 & 100.0 \\
\hline \multirow{2}{*}{ Teachers } & f & 0 & 0 & 6 & 98 & 345 & 449 \\
\cline { 2 - 8 } & f\% & .0 & .0 & 1.3 & 21.8 & 76.8 & 100.0 \\
\hline \multirow{2}{*}{ Total } & f & 1 & 8 & 120 & 887 & 1037 & 2053 \\
\cline { 2 - 8 } & f\% & .0 & .4 & 5.8 & 43.2 & 50.5 & 100.0 \\
\hline
\end{tabular}

Parents show a statistically significant difference $(\mathrm{c} 2=20.915 ; \mathrm{g}=8$, a $=0.007$ ) in their attitudes to the statement that the cooperation of school and parents is useful, in function of the achieved level of education. Their most frequent answer is that they agree with the statement. The answer "I absolutely agree" was the most frequently chosen $(46.4 \%)$ by parents with the highest level of education and the least frequently $(38.9 \%)$ by parents with primary and vocational education. The answer that they partially agree was chosen by $9.8 \%$ 
of parents with the lowest level of education and by $5.8 \%$ of parents with the highest education. In our case, parents with higher education show a much greater extent of agreement with the statement that the cooperation of parents and school is necessary and useful. This may be because most of them see their role in a clearer way and feel more competent to help their children with their school obligations.

Table 2: Parents' attitudes to the benefits and necessity of mutual cooperation in relation to their education.

\begin{tabular}{|c|c|c|c|c|c|c|c|c|}
\hline & & & \multicolumn{6}{|c|}{ Cooperation of school and parents is necessary and useful. } \\
\hline & & & $\begin{array}{c}\text { I absolutely } \\
\text { disagree }\end{array}$ & $\begin{array}{l}\text { I do not } \\
\text { agree }\end{array}$ & $\begin{array}{l}\text { I partially } \\
\text { agree }\end{array}$ & I agree & $\begin{array}{c}\text { I absolutely } \\
\text { agree }\end{array}$ & Total \\
\hline \multirow{8}{*}{ 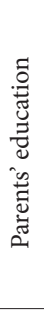 } & \multirow{2}{*}{$\mathrm{PS}+\mathrm{VS}$} & $\mathrm{f}$ & 1 & 6 & 44 & 222 & 174 & 447 \\
\hline & & f\% & .2 & 1.3 & 9.8 & 49.7 & 38.9 & 100.0 \\
\hline & \multirow{2}{*}{ SS } & $\mathrm{f}$ & 0 & 2 & 45 & 353 & 314 & 714 \\
\hline & & $\mathrm{f} \%$ & .0 & .3 & 6.3 & 49.4 & 44.0 & 100.0 \\
\hline & \multirow{2}{*}{$\begin{array}{l}\text { Coll.+Univ. } \\
\text { and above }\end{array}$} & $\mathrm{f}$ & 0 & 0 & 24 & 198 & 192 & 414 \\
\hline & & $\mathrm{f} \%$ & .0 & .0 & 5.8 & 47.8 & 46.4 & 100.0 \\
\hline & \multirow{2}{*}{ Total } & $f$ & 1 & 8 & 113 & 773 & 680 & 1575 \\
\hline & & $\mathrm{f} \%$ & .1 & .5 & 7.2 & 49.1 & 43.2 & 100.0 \\
\hline
\end{tabular}

Legend: PS = Primary school; VS = Vocational school; SS = Secondary school; Coll. = College; Univ. $=$ University

Compared to the share of parents with lower levels of education, it is evident that a larger share of parents with higher education are of the opinion that their cooperation with school is very sensible. Teachers need to be aware that in their work with less educated parents it will more often be necessary to help these parents to develop an awareness of their role in supporting the academic development of their children. Many of these parents probably even feel incompetent to help their children in learning, and they themselves need guidance in finding ways to help their children at home. Sometimes they only need some encouragement in order to talk with their children about their schoolwork and to show interest in their work, as this is an important way of participation. These are strategies of developing a "positive parenting role" (Lewis et al., 2011).

\section{Do parents see teachers as experts?}

The majority of teachers who responded $(81.2 \%)$ thought that parents see them as experts who know how to provide knowledge and to educate, while 
only $8.3 \%$ of teachers think that parents see them as people who know how to provide knowledge, but not how to educate. There is a high share of respondents who answered "Other" (10.5\%), where teachers stated answers such "I don't know", "I can't decide", etc.

Table 3: Teachers' opinions on how parents see them.

\begin{tabular}{|l|c|c|}
\hline \multicolumn{1}{|c|}{ What do you think is the parents' view of you? } & $\mathrm{f}$ & $\mathrm{f} \%$ \\
\hline You are experts who know how to provide knowledge and to educate & 362 & 81.2 \\
\hline You know how to provide knowledge, but not how to educate & 37 & 8.3 \\
\hline Other & 47 & 10.5 \\
\hline Total & 446 & 100.0 \\
\hline
\end{tabular}

As expected, parents were much more critical in their evaluation of teachers. Teachers were probably inclined to give the desired answers, since it is expected from them to both provide knowledge and educate, and as experts in both they also want to be seen as such by parents. Parents' answers differed in a statistically significant degree from teachers' answers $(\mathrm{c} 2=1.849 ; \mathrm{df}=3, \mathrm{p}$ $=0.000, \mathrm{n}=2063$ ).

Table 4: Parents' opinions about teachers.

\begin{tabular}{|l|c|c|}
\hline \multicolumn{1}{|c|}{ What is your general opinion of teachers? } & $\mathrm{f}$ & $\mathrm{f} \%$ \\
\hline They are experts who know how to provide knowledge and educate & 806 & 49.8 \\
\hline They know how to provide knowledge, but not how to educate & 678 & 41.9 \\
\hline They are not experts & 18 & 1.1 \\
\hline Other & 115 & 7.1 \\
\hline Total & 1617 & 100.0 \\
\hline
\end{tabular}

Only half of parents (49.8\%) judge that teachers are experts who know how to provide knowledge and educate. As many as $41.9 \%$ of parents believe that teachers know how to provide knowledge, but not how to educate. The category Other includes mostly responses from parents (7.1\%) that teachers differ a lot amongst themselves, and that such a judgment cannot be generalised to all teachers, since some are also excellent educators, while others do not get involved in education, which consequently gives rise to the question as to whether they have chosen the right profession.

Parents' opinions about teachers show a statistically significant difference in relation to their achieved education ( $c 2=52.02$; $\mathrm{df}=6, \mathrm{p}=0.000$, $\mathrm{n}=1586)$. 
Table 5: Parents' opinions about teachers in relation to their education.

\begin{tabular}{|c|c|c|c|c|c|c|c|}
\hline & & & \multicolumn{5}{|c|}{ What is your general opinion of teachers? } \\
\hline & & & $\begin{array}{l}\text { They are } \\
\text { experts }\end{array}$ & $\begin{array}{l}\text { They know how to } \\
\text { provide knowledge, } \\
\text { but not how to } \\
\text { educate }\end{array}$ & $\begin{array}{c}\text { They are not } \\
\text { experts }\end{array}$ & Other & Total \\
\hline \multirow{8}{*}{ 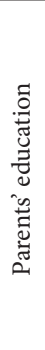 } & \multirow{2}{*}{$\mathrm{PS}+\mathrm{VS}$} & $\mathrm{f}$ & 283 & 168 & 8 & 12 & 471 \\
\hline & & $\mathrm{f} \%$ & 60.1 & 35.7 & 1.7 & 2.5 & 100.0 \\
\hline & \multirow{2}{*}{ SS } & $\mathrm{f}$ & 319 & 331 & 9 & 54 & 713 \\
\hline & & $\mathrm{f} \%$ & 44.7 & 46.4 & 1.3 & 7.6 & 100.0 \\
\hline & \multirow{2}{*}{$\begin{array}{l}\text { Coll.+Univ. } \\
\text { and above }\end{array}$} & $\mathrm{f}$ & 193 & 161 & 1 & 47 & 402 \\
\hline & & $\mathrm{f} \%$ & 48.0 & 40.0 & 0.2 & 11.7 & 100.0 \\
\hline & \multirow{2}{*}{ Total } & $\mathrm{f}$ & 795 & 660 & 18 & 113 & 1586 \\
\hline & & $\mathrm{f} \%$ & 50.1 & 41.6 & 1.1 & 7.1 & 100.0 \\
\hline
\end{tabular}

Legend: PS = Primary school; VS = Vocational school; SS = Secondary school; Coll. = College; Univ. $=$ University

From Table 5, it is evident that parents with primary and vocational education form the majority (60.1\%) of those who consider that teachers are experts for providing knowledge and education, while parents with at least secondary or further education indicate to an increasing degree that teachers are only experts for providing knowledge or that there are vast differences among them (category Other). For parents with the lowest education level, teachers in most cases still represent experts for providing knowledge and education, while parents with higher levels of education more often doubt teachers' expertise and are much more critical in their opinion of teachers. Above all, parents with the highest levels of education most often additionally explain their opinions and point out that teachers are varied and that it is difficult to give a single opinion of all teachers. We assume that among the parents with higher levels of education who are critical towards teachers, there are more of those who would try to push a teacher into a subordinate role in terms of exercising the so-called consumer model of teacher-parent cooperation (in Hornby, 2000). In such cases, it is important that teachers are backed up by the school management, who should support teachers' autonomy and offer them opportunities to continue their training for working with parents and their professional development. On the other hand, among parents with lower education levels there are more of those who need teachers' assistance in developing their full powers. 


\section{Do parents know how to be parents?}

In establishing a partnership it is important for parents to competently fulfil their role, to believe in their own powers, and also for teachers to attribute them this power (O'Callaghan, 1993 in Čačinovič-Vogrinčič, 1999). We asked parents and teachers about the extent to which they agree with the statement that parents know how to be parents today, and in their answers to this question both groups show statistically significant differences $\left(\chi^{2}=2.24 ; \mathrm{df}=4\right.$, $\mathrm{p}=0.000, \mathrm{n}=2062$ ).

Table 6: Presentation of parents' and teachers' attitudes towards the question as to whether parents today know how to be parents.

\begin{tabular}{|l|l|c|c|c|c|c|c|}
\hline \multicolumn{2}{|c}{} & \multicolumn{7}{|c|}{ Parents today know how to be parents. } \\
\cline { 3 - 8 } & $\begin{array}{c}\text { I absolutely } \\
\text { disagree }\end{array}$ & $\begin{array}{c}\text { I don't } \\
\text { agree }\end{array}$ & $\begin{array}{c}\text { I partially } \\
\text { agree }\end{array}$ & I agree & $\begin{array}{c}\text { I absolutely } \\
\text { agree }\end{array}$ & \multirow{2}{*}{ Total } \\
\hline \multirow{3}{*}{ Parents } & f & 20 & 76 & 651 & 663 & 198 & 1608 \\
\cline { 2 - 8 } & f\% & 1.2 & 4.7 & 40.5 & 41.2 & 12.3 & 100.0 \\
\hline \multirow{3}{*}{ Teachers } & f & 4 & 52 & 329 & 67 & 2 & 454 \\
\cline { 2 - 8 } & f\% & 0.9 & 11.5 & 72.5 & 14.8 & 0.4 & 100.0 \\
\hline \multirow{3}{*}{ Total } & f & 24 & 128 & 980 & 730 & 200 & 2062 \\
\cline { 2 - 8 } & f\% & 1.2 & 6.2 & 47.5 & 35.4 & 9.7 & 100.0 \\
\hline
\end{tabular}

More than half of parents (53.5\%) agree or absolutely agree with the statement that parents know how to be parents, while $40.5 \%$ partially agree with the statement and only a small percentage of parents do not agree or do not agree at all (5.9\%). Teachers are much more critical towards parents in responding to this question, as a mere $15.2 \%$ of teachers agree with the statement, while $72.5 \%$ of teachers partially agree and $12.4 \%$ do not agree with the statement. Teachers therefore doubt to a greater extent whether parents today can be parents - that they are experts in the area of their own child's development and education.

It is interesting to note that parents with higher education are much more critical towards themselves, as the share of parents partially agreeing with the statement grows with the increased level of their education (33.8\% to $46.2 \%$ of the most educated parents), while the share of those who agree or absolutely agree with the statement (60.1\% to $46.7 \%$ of the most educated parents) 
decreases. ${ }^{4}$ These differences among parents are statistically significant $\left(\chi^{2}=\right.$ 18.57; $\mathrm{df}=8, \mathrm{p}=0.017, \mathrm{n}=1578$ ).

In relation to this, we asked parents and teachers about the extent to which they agree with the statement that parents need to be additionally educated about parenting and problems of family education. In their response to this question, both groups show statistically significant differences $\left(\chi_{2}^{2}=1.98\right.$; $\mathrm{df}=4, \mathrm{p}=0.000, \mathrm{n}=2057)$. More than a third of parents $(36.1 \%)$ expressed agreement with the statement that they need additional education on problems of family education, while a similar proportion of parents (35.3\%) partly agreed with the statement and less than a third of parents (28.6\%) expressed their disagreement. In contrast, as many as $65.1 \%$ of teachers believe that parents need additional family-related education, while approximately one third (32.3\%) partially agree with the statement and only $2.7 \%$ of teachers do not agree. Teachers are therefore inclined to believe that parents need additional parenting-related education and, from their point of view, planning of cooperation forms such as "school for parents" enriches cooperation between the school and home. According to the results, more than a third of parents would be responsive to such an offer, while other parents are not convinced or have different expectations of school. This again shows that with such a proposal teachers can primarily approach parents with higher education.

The results therefore show that both groups express a degree of mutual doubt in the other's competence, and it is certainly difficult to build a partnership and fruitful cooperation on such grounds (Hornby, 2000).

\section{Obstacles to cooperation between teachers and parents}

Both teachers and parents are largely convinced that there are no obstacles to their cooperation. However, this opinion is more prevalent among parents than among teachers. Teachers more frequently stated that the main obstacle was the overburdening of parents; the next was laying the blame for everything on the teachers (stated by parents), and finally poor familiarity with each other. Parents agreed that the reason for obstacles is poor familiarity with

4 Due to extensive text, the results are not in the form of a table in the case of this research question and for another two research questions presented later in which we ask about differences between teachers' and parents' answers and in parents' answers in relation to their achieved education level. Nevertheless, detailed descriptions are given, as the results significantly complement and shed light on various views of teachers and parents or parents in relation to their achieved education level. 
each other, and they also placed stress on being overburdened. It is noteworthy that teachers refer to the overburdening of parents as one of the obstacles more often than parents. Probably they do not have a proper insight into what limits their mutual cooperation, and this is also indicated by the answer that they are limited by poor familiarity with each other. Both teachers and parents did not suppose that bad experiences in regard to their mutual cooperation might be the reason for obstacles - they mentioned it in an almost negligible percentage.

Table 7: What is the biggest obstacle to cooperation between teachers and parents?

\begin{tabular}{|l|c|c|c|c|}
\hline \multirow{2}{*}{} & \multicolumn{2}{|c|}{ Teachers } & \multicolumn{2}{c|}{ Parents } \\
\cline { 2 - 5 } & $\mathrm{f}$ & $\mathrm{f} \%$ & $\mathrm{f}$ & $\mathrm{f} \%$ \\
\hline Blaming teachers/parents & 64 & $\mathbf{1 4 . 4}$ & 69 & 4.4 \\
\hline Underestimation by parents/teachers & 18 & 4.1 & 46 & 2.9 \\
\hline Not knowing each other well & 60 & $\mathbf{1 3 . 5}$ & 269 & $\mathbf{1 7 . 1}$ \\
\hline Overburdening of teachers & 15 & 3.4 & 82 & 5.2 \\
\hline Overburdening of parents & 120 & $\mathbf{2 7 . 0}$ & 161 & $\mathbf{1 0 . 3}$ \\
\hline Bad experiences with parents/teachers & 1 & 0.2 & 16 & 1.0 \\
\hline Criticising teachers/children all the time & 15 & 3.4 & 65 & 4.1 \\
\hline There are no obstacles & 151 & $\mathbf{3 4 . 0}$ & 862 & $\mathbf{5 4 . 9}$ \\
\hline Total & 444 & 100 & 1570 & 100 \\
\hline
\end{tabular}

In mentioning obstacles to cooperation, parents' level of education is shown to be an important factor $\left(\chi_{2}=31.97 ; \mathrm{df}=14, \mathrm{p}=0.004\right)$. More parents with a higher level of education feel that there are obstacles to their cooperation with teachers $51.0 \%$ of parents with a university degree and $60.4 \%$ of parents with elementary education said that there were no obstacles). Poor familiarity with each other is given as a reason significantly less frequently among parents with elementary education (11.7\%) than among parents with higher education $(21 \%)$. Criticising their children all the time is most frequently cited as a reason by parents with elementary education (5.1\%) and the least frequent by parents with a high level of education (1.8\%). The findings again indicate the fact the parents are very diverse, with different expectations and needs, and consequently need to be attracted to and involved in cooperation with school or teachers in various ways.

\section{Conclusion}

Numerous authors who have studied cooperation between teachers and parents stress the importance of such cooperation for pupils' achievement and 
quality of schooling (for example, Burden, 1995; Gonzalez-DeHass et al., 2005; Henderson \& Berla, 1994; Hornby, 2000; Jordan et al., 2001; Lewis et al., 2011; Pomerantz et al., 2007; Soo-Yin, 2003). Teachers and parents in our research agree that mutual cooperation is useful and necessary. Among teachers there is a much bigger share of those who absolutely agree with the statement, while among parents those with a higher level of education show a larger extent of agreement with the statement.

The research showed that building positive mutual relationships between teachers and parents is a prerequisite for improving successful cooperation. This inevitably presupposes compliance with basic principles of mutual respect and acceptance of the individual differences, interests and needs of various groups of parents. Both teachers and parents express doubt in each other's competence. Although the majority of teachers $(81.2 \%)$ are of the opinion that parents see them as people who know how to present knowledge and to educate, only half of parents (49.8\%) agree with this. For most parents with the lowest education level, teachers still represent an authority in both areas, schooling and education, while parents with higher levels of education are more critical in their opinions. More than half of parents (53.5\%) agree or absolutely agree with the statement that parents know how to be parents. Regarding this question, parents with higher education are more self-critical, as more of them only partially agree with the statement compared with parents who are less educated. Parents with higher education are also more inclined to accept additional education on parenthood and the problems of family education. Similar to those parents who are more critical towards teachers, the latter are even more critical towards parents, as only $15.2 \%$ of teachers agree with the statement that today parents know how to be parents. Teachers' and parents' opinions of each other therefore represent one of the key obstacles to increasing the quality of mutual cooperation, since mutual respect and recognition is a prerequisite to building a partnership relation (Hornby, 2000).

Among the obstacles to mutual cooperation, teachers most frequently mention the overburdening of parents, laying the blame on teachers and not knowing each other well enough, while parents primarily highlight poor familiarity with each other and their own overburdening. Therefore, when planning mutual cooperation, each particular school should look for methods with which they can attract parents with their varied characteristics and provide possibilities for improved mutual understanding. Lewis et al. (2011) point out that parents' participation increases when teachers demonstrate more receptive and supportive attitudes toward parental participation, when they show parents that they care about their child and that parents' help is welcome and needed. 
The proposals of our research are strongly in line with findings of previous studies (Kalin, 2001, 2004); namely, that in the field of teacher-parent cooperation it is necessary to build a culture of dialogue and problem solving in an atmosphere of respect and acceptance of the differing characteristics of both teachers and parents, and that it is necessary to constantly reflect on the current situation and on this basis develop higher quality and more efficient ways of cooperation between schools and parents. An essential starting point of any culture of good cooperation is allowing each other freedom and autonomy, awareness of interdependence and common goals. These are the very foundations on which it is possible to build a culture of partnership in cooperation between teachers and parents.

\section{References}

Bečaj, J. (1999). Organizacijska struktura šole, vodenje in položaj svetovalne službe [The organisational structure of school, leadership and the position of the counselling service]. In M. Resman (Ed.), Svetovalno delo v vrtcih, osnovnih in srednjih šolah [Counselling work in kindergartens, primary schools and secondary schools] (pp. 157-174). Ljubljana: The National Education Institute of the Republic of Slovenia.

Burden, P. R. (1995). Classroom Management and Discipline. Methods to Facilitate Cooperation and Instruction. New York: Longman Publishers USA.

Čačinovič-Vogrinčič, G. (1999). Svetovalno delo s starši, svetovalno delo z družinami [Counselling work with parents, counselling work with families]. In M. Resman (Ed.), Svetovalno delo v vrtcih, osnovnih in srednjih šolah [Counselling work in kindergartens, primary schools and secondary schools] (pp. 175-191). Ljubljana: The National Education Institute of the Republic of Slovenia.

Esler, A. N., Godber, Y., \& Christenson, S. L. (2002). Best practices in supporting home-school collaboration. In A. Thomas, \& J. Grimes (Eds.), Best practices in school psychology IV (pp. 389-411).

Bethesda, MD: NASP.

Gonzalez-DeHass, A. R., Willems, P. P., \& Doan Holbein, M. F. (2005). Examining the Relationship Between Parental Involvement and Student Motivation. Educational Psychology Review, 17(2), 99-123. Henderson, A. T., \& Berla, N. (Eds.) (1994). A new generation of evidence: The family is critical to student achievement. Washington, DC: National Committee for Citizens in Education. Holly, P., \& Southworth, G. (1989). The Developing School. London: The Falmer Press. Hornby, G. (2000). Improving Parental Involvement. London and New York: Cassell. Jaques, D. (2000). Learning in groups. London: Kagan Page.

Jordan, C., Orozco, E., \& Averett, A. (2001). Emerging Issues in School, Family, \& Community Connections. Annual Synthesis 2001. Austin, Texas: National Center for Family \& Community Connections with Schools, Southwest Educational Development Laboratory. Retrieved on 28.07.2008 from www.sedl.org/connections. 
Kalin, J. (2001). Views of the Work and Roles of the Class Teacher. Sodobna pedagogika

[Contemporary Education], 52(1), 8-31.

Kalin, J. (2004). Qualified Home-room Teachers. Pedagoška obzorja [Educational Horizons], 19(2), 3-14.

Kalin, J., Govekar-Okoliš, M., Mažgon, J., Mrvar, P., Resman, M., \& Šteh, B. (2008). Vzvodi uspešnega sodelovanja med domom in šolo: sodobne rešitve in perspektive [Levers of successful cooperation between the school and the home: modern solutions and perspectives, Research report]. Ljubljana: University of Ljubljana, Faculty of Arts.

Kalin, J., \& Šteh, B. (2008). Factors for the successful cooperation between teachers and parents in ensuring high quality education and a fulfilling school life. In N. Popov (Ed.), Comparative education, teacher training, education policy and social inclusion, Vol. 6 (pp. 72-81). Sofia: Bureau for Educational Services.

Kottler, J. A., \& Kottler, E. (2001). Svetovalne spretnosti za vzgojitelje in učitelje [Counselling skills for the kindergarten teacher and teacher]. Ljubljana: Institute of Personal Psychology.

Lewis, L. L., Kim, Y. A., \& Bey, J. A. (2011). Teaching practices and strategies to involve inner-city parents at home and in the school. Teaching and Teacher Education: An International Journal of Research and Studies, 27(1), 221-234.

Pomerantz, E. M, Moorman, E. A., \& Litwack, S. D. (2007). The How, Whom, and Why of Parents' Involvement in Children's Academic Lives: More Is Not Always Better. Review of Educational Research, 77(3), 373-410.

Soo-Yin, L. (2003). Parent Involvement in Education. In G. Olsen, \& M. L. Fuller (Eds.), HomeSchool Relations (pp. 134-158). Boston: Allyn and Bacon.

Šteh, B., \& Mrvar, P. (2011a). Pomen vzpostavljanja kakovostnih medosebnih odnosov pri sodelovanju med šolo in starši [The significance of establishing quality interpersonal relationships in cooperation between school and parents]. In T. Vidmar, \& J. Aksman (Eds.), Pedagoško-andragoške razprave $v$ Sloveniji in na Poljskem po prelomu stoletja [Pedagogical-andragogical discussion in Slovenia and Poland at the turn of the century] (pp. 59-77). Ljubljana: Znanstvena založba, Faculty of Arts, University of Ljubljana.

Šteh, B., \& Mrvar, P. (2011b). Stališča in pričakovanja učiteljev, svetovalnih delavcev in staršev drug do drugega $\mathrm{v}$ kontekstu sodelovanja med šolo in domom [The viewpoints and expectations of teachers, counsellors and parents with regard to each other in the context of cooperation between school and home]. Psihološka obzorja [Psychological Horizons], 20(1), 17-41.

Woolfolk, A. (2002). Pedagoška psihologija [Educational Psychology]. Ljubljana: Educy. 


\section{Biographical note}

Jana Kalin, PhD, is an associate professor of didactics and lectures at the Faculty of Arts at the Department Educational Sciences, University of Ljubljana, Slovenia. Her research work in recent years encompasses the field of professional development of teachers, the quality of higher education, ability grouping in education, the assessment of knowledge, and the cooperation between school and parents. Jana Kalin regularly presents papers at the domestic and international scientific conferences and publishes in scientific and professional publications.

Barbara Šteh, $\mathrm{PhD}$ in psychology, is an Assistant Professor of Educational psychology at the Department of Educational Sciences at the Faculty of Arts of the University of Ljubljana. Her research interests include the quality of teaching/learning, implementation of active learning methods, the cooperation between school and parents, teacher autonomy and professional development. In her own teaching, she implements active and experience-based teaching methods and mentors many students. She also runs many workshops and seminars for in-service teacher training for teachers at all levels and educational advisors. 